\title{
Effects of dietary supplementation with rice bran oil on the growth performance, blood parameters, and immune response of broiler chickens
}

\author{
Hwan Ku Kang and Chan Ho Kim ${ }^{*}$
}

\begin{abstract}
Background: The objective of this experiment was to investigate the effects of dietary supplementation of rice bran oil (RBO) on growth performance, blood parameter, and immune response in broiler chickens.

Methods: A total of 240 1-d-old ROSS 308 male broilers were randomly allotted to 4 dietary treatments with six replicated pens consisting of ten chicks. The basal diet was formulated to be adequate in energy and nutrients. Three additional diets were prepared by adding 5, 10 or $20 \mathrm{~g} / \mathrm{kg}$ of RBO to the basal diet. The experimental diets were fed on an ad libitum basis to the birds during $35 \mathrm{~d}$.

Results: Results indicated that increasing inclusion level of RBO in diets improved BW gain (linear and quadratic, $P<0.01$ ), improve feed conversion ratio (linear, $P<0.05$ ) of birds during 0 to $35 \mathrm{~d}$. There was no effect of inclusion level of RBO in diets on feed intake of birds. There was no effect of inclusion level of RBO in diets on erythrocytes of birds. However, heterophil, lymphocyte, and monocytes increased (linear and quadratic, $P<0.01$ ) with inclusion level of RBO in diets increased. Feeding the diets containing increasing amount of RBO to birds increased (linear, $P<0.01)$ the concentrations of total cholesterol. Increasing inclusion level of RBO in diets increased concentrations of $\operatorname{lgG}$ (linear, $P<0.01$ ). There was no effect of inclusion level of RBO in diets on concentrations of IgM.
\end{abstract}

Conclusions: These results suggest that dietary RBO may be used functional ingredient to improve growth performance, total cholesterol in serum, and immune response of birds.

Keywords: Broiler, Growth performance, Rice bran oil, Total cholesterol

\section{Background}

Currently, consumers are increasingly aware of the health benefits and nutritional quality of the food they consume [1]. Rice is the principle cereal food in Korea, and the by-products from its milling are used as important feed resources. Rice bran, a by-product of rice milling, contains high levels of important nutrients, such as proteins, vitamins, minerals, complex carbohydrates, phytonutrients, phospholipids and essential fatty acids [2-4]. Rice bran is an effective dietary energy and unsaturated fatty acid source for animals such as chickens,

\footnotetext{
* Correspondence: kch8059@korea.kr

Poultry Science Division, National Institute of Animal Science, RDA,

Seonghwan-eup, Cheonan-si, Chungcheognam-do 330-801, Republic of Korea
}

(c) 2016 Kang and Kim. Open Access This article is distributed under the terms of the Creative Commons Attribution 4.0 International License (http://creativecommons.org/licenses/by/4.0/, which permits unrestricted use, distribution, and reproduction in any medium, provided you give appropriate credit to the original author(s) and the source, provide a link to the Creative Commons license, and indicate if changes were made. The Creative Commons Public Domain Dedication waiver (http://creativecommons.org/publicdomain/zero/1.0/) applies to the data made available in this article, unless otherwise stated.

rats and pigs with relatively minor effects on growth and performance [5]. One such by-product is rice bran oil (RBO); it is gaining commercial importance worldwide because of its many beneficial nutritive and biological effects. Rice bran oils contains $90-96 \%$ saponifiable lipids and about $4 \%$ unsaponifiable lipids. The saponifiable lipids include $68-71 \%$ triglycerides, 2-3 \% diglycerides, 5-6\% monoglycerides, $2-3 \%$ free fatty acids (FFAs), $2-3 \%$ waxes, 5-7 \% glycolipids, and 3-4\% phospholipids [6], whereas the principle component of the unsaponifiable fraction is $\gamma$-oryzanol [7]. RBO can be extracted from rice bran by using solvent extraction with food-grade $n$-hexane [8], via a solvent-free process by using ohmic heating [9], or by extraction using ethanol [10]. $\gamma$-oryzanol, a phytosterylferulate mixture extracted from rice bran oil, has a 
wide spectrum of biological activities, as well as antioxidant properties [11]. RBO has an excellent fatty acid profile. Three major fatty acids, palmitic, oleic, and linoleicaccount for $90 \%$ of the total fatty acids of rice bran extracts [12]. Previous studies on dietary supplementation of rice bran oil in broilers have shown improved growth performance $[13,14]$ and decreased cholesterol concentrations [15]. Dietary supplementation of rice bran in mice have shown improved immune response [16]. However, data pertaining to the effects of dietary supplementation of RBOon the growth performance, blood parameters, and immune response of broilersare limited. Therefore, the objective of the present study was to investigate the effect of dietary supplementation of rice bran extracts on the growth performance, blood parameters, immune responseof broilers.

\section{Methods}

The protocol for this experiment was reviewed and approved by the Institutional Animal Care and Welfare Committee of the National Institute of Animal Science, Rural Development Administration, Republic of Korea.

\section{Preparation of rice bran oil (RBO)}

Rice bran harvested in 2014 was obtained from a rice processing complex (Seonghwan-eup, South Korea). RBO was extracted as described previously ([10] Fig. 1). The nutrient composition of RBO was analyzed in duplicate for crude fat [17]. The results are presented in Table 1.

\section{Birds and experimental design}

A total of 2401 -d-old ROSS 308 male broilers (initial $\mathrm{BW}=36 \pm 0.74 \mathrm{~g}$ ) were obtained from local hatchery (Samhwa Hatchery, Hongseong, Republic of Korea) and were housed in a battery cages $(86 \mathrm{~cm} \times 57 \mathrm{~cm} \times 35 \mathrm{~cm}$,

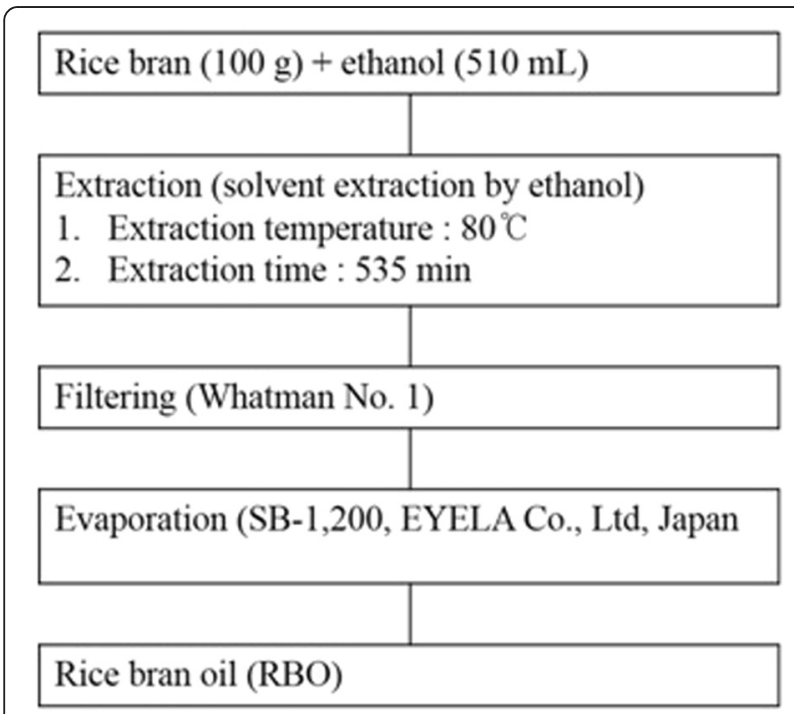

Fig. 1 Scheme for extraction process from rice bran
Table 1 Analyzed fatty acids composition of rice bran oil (RBO) used in this experiment (as is basis)

\begin{tabular}{ll}
\hline Composition & Rice bran oil (RBO) \\
\hline Crude fat (g/kg) & 305.1 \\
Fatty acids composition & $\mathrm{g} / \mathrm{kg}$ \\
Myristic acid (C14:0) & 3.6 \\
Palmitic acid (C16:0) & 179.6 \\
Palmitoleic acid (C16:1n7) & 2.1 \\
Stearic acid (C18:0) & 0.6 \\
Vaccenicacid (C18:In7) & 13.1 \\
Oleic acid (C18:1n9) & 422.5 \\
Linoleic acid (C18:2n6) & 378.5 \\
Total & $1,000.0$ \\
Saturated fatty acid & 183.8 \\
Unsaturated fatty acid & 816.2 \\
Mono unsaturated fatty acid & 433.7 \\
Poly unsaturated fatty acid & 378.5 \\
\hline
\end{tabular}

${ }^{a}$ Nutrient composition was analyzed for crude fat (AOAC, 1995; method 920.39)

width $\times$ length $\times$ height) in an environmentally controlled room. The experiment was performed as a completely randomized design with six replicate pens consisting of ten chicks. A 2-phase feeding program with a starter diet from 0 to $21 \mathrm{~d}$ and a grower diet from 22 to $35 \mathrm{~d}$ was used in this experiment (Table 2). Within each phase, a control diet was formulated to meet or exceed NRC [18] requirements of broiler chickens for macro- and micronutrients. Three additional diets were prepared by adding 5,10 or $20 \mathrm{~g} / \mathrm{kg}$ of RBO to the basal diet. The RBOwas added at the expense of the basal diet. The experimental diets were mash form. The diets and water were availablead libitum. The room temperature for both conventional and battery cages was maintained at $30{ }^{\circ} \mathrm{C}$ during the first week of the experiment and then gradually decreased to $24{ }^{\circ} \mathrm{C}$ at the end of the experiment as recommended by the Ross manual. A 24-h lighting schedule was used throughout the experiment.

\section{Growth performance}

Body weight gain and feed intake were recorded at 21 and $35 \mathrm{~d}$ of the experiment. Feed conversion ratio was calculated as feed intake divided by BW gain.

\section{Sample collection and analysis}

At the end of the 35-day feeding trial, 1 bird with a BW close to the pen BW (i.e. six birds) was selected and euthanized by cervical dislocation. Immediately after euthanasia, a $5 \mathrm{~mL}$ blood sample was collected from the jugular vein by using EDTA vacuum tubes (Becton Dickinson, Franklin Lakes, NJ), stored on ice, and subjected to immediate hematological analysis. Leukocytes (white blood cells, heterophils, lymphocytes, monocytes, 
Table 2 Composition and nutrient content of experimental diets (as-fed basis)

\begin{tabular}{|c|c|c|c|c|c|c|c|c|}
\hline \multirow[t]{2}{*}{ Item } & \multicolumn{4}{|c|}{$\begin{array}{l}\text { Starter period (0 to } 21 \mathrm{~d}) \\
\text { Rice bran oil }(\mathrm{g} / \mathrm{kg})\end{array}$} & \multicolumn{4}{|c|}{$\begin{array}{l}\text { Grower period ( } 22 \text { to } 35 \mathrm{~d}) \\
\text { Rice bran oil }(\mathrm{g} / \mathrm{kg})\end{array}$} \\
\hline & 0 & 5 & 10 & 20 & 0 & 5 & 10 & 20 \\
\hline \multicolumn{9}{|l|}{ Ingredients, g/kg } \\
\hline Maize & 509.1 & 504.1 & 499.1 & 489.1 & 598.9 & 593.9 & 588.9 & 578.9 \\
\hline Soybean meal (450 g/kg CP) & 356.4 & 356.4 & 356.4 & 356.4 & 322.2 & 322.2 & 322.2 & 322.2 \\
\hline Corn gluten meal & 35.0 & 35.0 & 35.0 & 35.0 & - & - & - & - \\
\hline Soybean oil & 60.0 & 60.0 & 60.0 & 60.0 & 45.0 & 45.0 & 45.0 & 45.0 \\
\hline Dicalcium phosphate & 18.6 & 18.6 & 18.6 & 18.6 & 13.5 & 13.5 & 13.5 & 13.5 \\
\hline Limestone & 15.4 & 15.4 & 15.4 & 15.4 & 15.2 & 15.2 & 15.2 & 15.2 \\
\hline Methionine-99 \% & 1.5 & 1.5 & 1.5 & 1.5 & 1.2 & 1.2 & 1.2 & 1.2 \\
\hline $\mathrm{NaCl}$ & 2.0 & 2.0 & 2.0 & 2.0 & 2.0 & 2.0 & 2.0 & 2.0 \\
\hline Vitamin-mineral premix ${ }^{a}$ & 1.0 & 1.0 & 1.0 & 1.0 & 1.0 & 1.0 & 1.0 & 1.0 \\
\hline Sodium bicarbonate & 1.0 & 1.0 & 1.0 & 1.0 & 1.0 & 1.0 & 1.0 & 1.0 \\
\hline Rice bran oil & - & 5.0 & 10.0 & 20.0 & - & 5.0 & 10.0 & 20.0 \\
\hline Total & $1,000.0$ & $1,000.0$ & $1,000.0$ & $1,000.0$ & $1,000.0$ & $1,000.0$ & $1,000.0$ & $1,000.0$ \\
\hline \multicolumn{9}{|l|}{ Energy and nutrient content ${ }^{\mathrm{b}}$} \\
\hline$M E_{n}(M J / k g)$ & 13.1 & 13.1 & 13.1 & 13.1 & 13.0 & 13.0 & 13.0 & 13.0 \\
\hline Crude protein (g/kg) & 230.0 & 230.0 & 230.0 & 230.0 & 200.0 & 200.0 & 200.0 & 200.0 \\
\hline Calcium (g/kg) & 10.0 & 10.0 & 10.0 & 10.0 & 9.0 & 9.0 & 9.0 & 9.0 \\
\hline Avaiable P (g/kg) & 4.3 & 4.3 & 4.3 & 4.3 & 3.5 & 3.5 & 3.5 & 3.5 \\
\hline Lysine (g/kg) & 11.9 & 11.9 & 11.9 & 11.9 & 10.8 & 10.8 & 10.8 & 10.8 \\
\hline Methione + cysteine (g/kg) & 8.5 & 8.5 & 8.5 & 8.5 & 7.2 & 7.2 & 7.2 & 7.2 \\
\hline
\end{tabular}

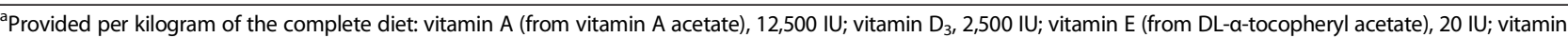
$\mathrm{K}_{3}, 2 \mathrm{mg}$; vitamin $\mathrm{B}_{2}, 5 \mathrm{mg}$; vitamin $\mathrm{B}_{6}, 3 \mathrm{mg}$; vitamin $\mathrm{B}_{12}, 18 \mu \mathrm{g}$; calcium pantothenate, $8 \mathrm{mg}$; folic acid, $1 \mathrm{mg}$; biotin, $50 \mu \mathrm{g} ;$ niacin, $24 \mathrm{mg}$; $\mathrm{Zn}$ (as $\mathrm{ZnO}$ ), $60 \mathrm{mg}$; Mn (as $\mathrm{MnSO}_{2} \cdot \mathrm{H}_{2} \mathrm{O}$ ), $50 \mathrm{mg} ; \mathrm{Fe}\left(\right.$ as $\mathrm{FeSO}_{4} \cdot 7 \mathrm{H}_{2} \mathrm{O}$ ), $50 \mathrm{mg}$; Cu (as $\mathrm{CuSO}_{4} \cdot 5 \mathrm{H}_{2} \mathrm{O}$ ), $6 \mathrm{mg}$; Co (as CoCO3), $250 \mu \mathrm{g} ; \mathrm{I}\left[\right.$ as $\left.\mathrm{Ca}\left(\mathrm{IO}_{3}\right)_{2} \cdot \mathrm{H}_{2} \mathrm{O}\right], 1 \mathrm{mg} ; \mathrm{Se}\left(\right.$ as Na $\left.\mathrm{NeO}_{3}\right), 150 \mu \mathrm{g}$

${ }^{\mathrm{b}}$ Nutrient contents in all diet were calculated were analyzed

eosinophils, basophils) and erythrocytes (red blood cells, hemoglobin, hematocrit, and mean corpuscular hemoglobin concentration) were quantified using Hemavet Multispecies Hematology Systems (Drew Scientific Inc., Oxford, CT). Immediately after the blood analysis, serum samples, obtained by centrifuging the samples for $20 \mathrm{~min}$ at $25,000 \times g$ and $4{ }^{\circ} \mathrm{C}$, were stored at $-15{ }^{\circ} \mathrm{C}$. Aspartate aminotransferase (AST), alanine aminotransferase (ALT), glucose, total cholesterol, and albumin in the serum were quantified using an ADVIA 1650 chemistry system (Bayer diagnostic, Putraux, France). The serum samples were used to measure the concentrations of IgG and IgM isotype, using chicken IgG or IgM ELISA quantitation kits (Bethyl Laboratories, Montgomery, TX). Briefly, flat bottomed microtiter plates were coated for 60 min with capture antibody (goat anti-chicken IgG or IgM affinity purified) and coating buffer (0.05 M carbonate-bicarbonate, $\mathrm{pH}$ 9.6). Plates were washed 3 times with washing solution (50 mMTris-buffered saline, $0.14 \mathrm{M} \mathrm{NaCl}, 0.05 \%$ Tween 20 , pH 8.0), and wells were incubated with blocking solution (50 mMTris-buffered saline, $0.14 \mathrm{M} \mathrm{NaCl}, 1 \%$
$\mathrm{BSA}, \mathrm{pH}$ 8.0) for $30 \mathrm{~min}$ then rinsed 3 times with washing solution. The calibrator (chicken reference plasma) and sample-conjuate diluent (50 mM Tris-buffered saline, $0.14 \mathrm{mM} \mathrm{NaCl}, 1 \%$ BSA, $0.05 \%$ Tween 20, $\mathrm{pH}$ 8.0) were used to do standards, whereas plasma samples, thawed at $4{ }^{\circ} \mathrm{C}$ overnight, were diluted at 1:1,000 in the sample-conjugate diluent. Then, they were incubated in wells for $60 \mathrm{~min}$ and washed 5 times with washing solution. Detection antibody horserasishperosidase (goat anti-chicken IgG or IgM) diluted in sample-conjugate diluent was added to wells, incubated for $60 \mathrm{~min}$, and rinsed 5 times with washing solution. Enzyme substrate (3, 3', 5, 5'-tetramethyl benzidine peroxidase substrate and peroxidase solution $\mathrm{B}$ ) was added and incubated for $15 \mathrm{~min}$ (IgM) or $30 \mathrm{~min}$ (IgG). Finally, $2 \mathrm{M} \mathrm{H}_{2} \mathrm{SO}_{4}$ was used to stop the 3', 3-5, 5'-tetramethyl benzidine reaction. A microtiter plate reader (Spectramax 190, Molecular Device, USA) was used to measure the absorbance at $450 \mathrm{~nm}$. To calculate the immunoglobulin (IgG or IgM) concentration, a 4-parameter logistic curve fit was developed using the broiler chicken reference plasma absorbance. 
Table 3 Growth performance of broiler chickens fed the diet containing rice bran oil (RBO)

\begin{tabular}{|c|c|c|c|c|c|c|c|}
\hline \multirow[t]{2}{*}{ Item } & \multicolumn{4}{|c|}{ Dietary treatments ${ }^{b}$} & \multirow[t]{2}{*}{ Pooled SEM ${ }^{c}$} & \multicolumn{2}{|c|}{$P$-value } \\
\hline & 0 & 5 & 10 & 20 & & Linear & Quadratic \\
\hline \multicolumn{8}{|l|}{0 to $21 \mathrm{~d}$} \\
\hline BW gain (g/bird) & 720.5 & 763.4 & 769.2 & 774.5 & 13.52 & 0.02 & 0.20 \\
\hline Feed intake (g/bird) & $1,095.8$ & $1,033.1$ & $1,008.3$ & 985.4 & 49.62 & 0.14 & 0.70 \\
\hline Feed conversion ratio & 1.50 & 1.35 & 1.31 & 1.27 & 0.07 & 0.02 & 0.34 \\
\hline \multicolumn{8}{|l|}{22 to $35 \mathrm{~d}$} \\
\hline BW gain (g/bird) & 835.4 & 931.8 & 907.7 & 895.6 & 14.91 & 0.04 & $<0.01$ \\
\hline Feed intake (g/bird) & $1,739.4$ & $1,736.3$ & $1,689.4$ & $1,659.8$ & 84.44 & 0.27 & 0.87 \\
\hline Feed conversion ratio & 2.15 & 1.86 & 1.86 & 1.86 & 0.09 & 0.07 & 0.18 \\
\hline \multicolumn{8}{|l|}{0 to $35 \mathrm{~d}$} \\
\hline BW gain (g/bird) & $1,555.9$ & $1,695.2$ & $1,676.9$ & $1,670.1$ & 8.92 & $<0.01$ & $<0.01$ \\
\hline Feed intake (g/bird) & $2,889.3$ & $2,769.3$ & $2,697.8$ & $2,645.2$ & 119.5 & 0.17 & 0.79 \\
\hline Feed conversion ratio & 1.86 & 1.63 & 1.61 & 1.58 & 0.07 & 0.03 & 0.22 \\
\hline
\end{tabular}

${ }^{\mathrm{a}}$ Data are least squares means of 6 observations per treatments

${ }^{\mathrm{b}}$ Basal diet was supplemented with RBO at 5,10 , or $20 \mathrm{~g} / \mathrm{kg}$

${ }^{\mathrm{C}}$ Pooled standard error of the means

\section{Statistical analysis}

All data were analyzed by ANOVA according to completely randomized design [19] using the PROC MIXED procedure of SAS (SAS Institute Inc., Cary, NC). Outlier data were identified according to STEEL et al. [19], using the UNIVARIATE procedure of SAS, but no outliers were detected. The battery cage was an experimental unit for growth performance data, whereas the individual bird was an experimental unit for blood parameter, serum enzyme activities and immune response data. Dietary treatment was fixed effect in all statistical models. The LSMEANS procedure was used to calculate mean values. The orthogonal polynomial contrast test was performed to determine linear and quadratic effects of increasing inclusion level of RBO in diets on each measurement. Significance and tendency

Table 4 Blood parameter of broiler chickens fed the diet containing rice bran oil (RBO) ${ }^{a}$

\begin{tabular}{|c|c|c|c|c|c|c|c|}
\hline \multirow[t]{2}{*}{ Items } & \multicolumn{4}{|c|}{ Dietary treatments ${ }^{\mathrm{b}}$} & \multirow[t]{2}{*}{ Pooled SEM ${ }^{c}$} & \multicolumn{2}{|l|}{$P$-value } \\
\hline & 0 & 5 & 10 & 20 & & Linear & Quadratic \\
\hline \multicolumn{8}{|l|}{ Leukocytes $^{d}$} \\
\hline WBC $(K / \mu L)$ & 14.34 & 12.27 & 13.62 & 14.97 & 1.70 & 0.61 & 0.56 \\
\hline $\mathrm{HE}(\mathrm{K} / \mu \mathrm{L})$ & 0.28 & 2.15 & 2.23 & 2.06 & 0.30 & $<0.01$ & $<0.01$ \\
\hline $\mathrm{LY}(\mathrm{K} / \mu \mathrm{L})$ & 3.75 & 8.78 & 9.56 & 6.65 & 0.91 & $<0.01$ & $<0.01$ \\
\hline $\mathrm{MO}(\mathrm{K} / \mu \mathrm{L})$ & 0.30 & 1.14 & 1.35 & 0.91 & 0.13 & $<0.01$ & $<0.01$ \\
\hline $\mathrm{EO}(\mathrm{K} / \mu \mathrm{L})$ & 0.01 & 0.18 & 0.16 & 0.27 & 0.04 & 0.98 & 0.24 \\
\hline $\mathrm{BA}(\mathrm{K} / \mu \mathrm{L})$ & 0.00 & 0.03 & 0.02 & 0.04 & 0.02 & 0.18 & 0.25 \\
\hline \multicolumn{8}{|l|}{ Erythrocytes $^{e}$} \\
\hline $\mathrm{RBC}(\mathrm{M} / \mu \mathrm{L})$ & 2.48 & 2.54 & 2.61 & 2.27 & 0.09 & 0.65 & 0.20 \\
\hline $\mathrm{Hb}(\mathrm{g} / \mathrm{dL})$ & 9.83 & 10.03 & 10.07 & 9.40 & 0.26 & 0.76 & 0.25 \\
\hline HCT (\%) & 24.47 & 25.03 & 25.17 & 22.90 & 0.87 & 0.99 & 0.12 \\
\hline $\mathrm{MCV}(\mathrm{fL})$ & 98.60 & 98.43 & 96.80 & 100.95 & 1.64 & 0.54 & 0.78 \\
\hline $\mathrm{MCH}(\mathrm{pg})$ & 39.70 & 39.43 & 38.67 & 41.50 & 0.82 & 0.18 & 0.30 \\
\hline $\mathrm{MCHC}(\mathrm{g} / \mathrm{dL})$ & 40.23 & 40.10 & 40.00 & 41.05 & 0.79 & 0.46 & 0.36 \\
\hline
\end{tabular}

${ }^{a}$ Data are least squares means of 6 observations per treatments

${ }^{b}$ Basal diet was supplemented with RBO at 5,10 , or $20 \mathrm{~g} / \mathrm{kg}$

${ }^{c}$ Pooled standard error of the means

dLeukocytes: WBC white blood cells, HE heterophils, $L Y$ lymphocytes; heterophil : lymphocytes; $M O$ monocytes, EO eosinophils, $B A$ basophils

EErythrocytes: $R B C$ red blood cells, $H b$ hemoglobin, $H C T$ hematocrit, $M C V$ mean corpuscular volume, $M C H$ mean corpuscular hemoglobin, $M C H C$ mean corpuscular hemoglobin concentration 
Table 5 Serum enzyme activities of broiler chickens fed the diet containing rice bran oil (RBO) ${ }^{a}$

\begin{tabular}{|c|c|c|c|c|c|c|c|}
\hline \multirow[t]{2}{*}{ Items } & \multicolumn{4}{|c|}{ Dietary treatments ${ }^{b}$} & \multirow[t]{2}{*}{ Pooled SEM ${ }^{c}$} & \multicolumn{2}{|c|}{$P$-value } \\
\hline & 0 & 5 & 10 & 20 & & Linear & Quadratic \\
\hline AST(U/L) & 188.0 & 188.7 & 192.7 & 208.0 & 12.68 & 0.43 & 0.14 \\
\hline $\operatorname{ALT}(U / L)$ & 5.33 & 4.67 & 5.33 & 5.00 & 0.62 & 0.82 & 0.17 \\
\hline Total cholesterol (mg/dL) & 154.7 & 158.7 & 125.0 & 106.0 & 9.50 & $<0.01$ & 0.10 \\
\hline Glucose (mg/dL) & 243.3 & 262.7 & 258.7 & 253.0 & 6.66 & 0.92 & 0.08 \\
\hline Albumin (g/dL) & 1.33 & 1.40 & 1.33 & 0.93 & 0.08 & 0.59 & 0.28 \\
\hline
\end{tabular}

${ }^{a}$ Data are least squares means of 6 observations per treatments

${ }^{\mathrm{b}}$ Basal diet was supplemented with RBO at 5,10 , or $20 \mathrm{~g} / \mathrm{kg}$

'Pooled standard error of the means

for statistical tests were set at $P<0.05$ and $0.05 \leq P \leq 0.10$, respectively.

\section{Results and discussion}

During the initial $21 \mathrm{~d}$ of the experiment, $\mathrm{BW}$ gain and feed conversion ratio increased (linear, $P<0.05$ ) with inclusion level of RBE, but feed intake was not influenced by inclusion of RBE in diets (Table 3). During 22 to $35 \mathrm{~d}$ of the experiment, BW gain increased (linear and quadratic, $P<0.05$ ) with inclusion level of $\mathrm{RBO}$ and a tendency for improved feed conversion ratio (linear, $P<0.10)$ was observed as inclusion level of RBE in diets increased. There was no effect of inclusion level of RBO in diets on feed intake of birds. For overall experiment, increasing inclusion level of RBO in diets increased BW gain (linear and quadratic, $P<0.01$ ), and improved feed conversion ratio (linear, $P<0.05$ ). There was no effect of inclusion level of RBO in diets on feed intake of birds. Dietary supplementation of rice bran or rice bran extracts has been reported to improve BW gain in broilers [20, 21]. It is suggested that positive effects of dietary rice bran extracts on birds' performance may result from its high concentrations of oryzanols, tocopherols, vitamin E, ferulic acid, phytic acid, lecithin, and inositol [10, 22]. Advantages of utilizing oils in broiler diet include increase in absorption and digestion of lipoproteins, significance amount of necessary fatty acids [23-25]. In addition, the favorable results of vegetable oil diet on growth performance of birds could be explained by the positive effect of this fat sources on the reduced passage rate of the digesta through the gastrointestinal trait, allowing for better nutrient absorption and utilization [26], resulting in a more efficient use of nutrients from diet. There was no effect of inclusion level of RBE in diets on erythrocytes of birds. However, heterophil, lymphocyte, and monocytes increased (linear and quadratic, $P<0.01$ ) with inclusion level of RBE in diets increased (Table 4). Blood parameters are good indicators of physiological, pathological and nutritional status of an animal and changes in hematological parameters have the potential of being used to elucidate the impact of nutritional factors and additives supplied in diet on any living creature. For example, leukocytes are known to increase sharply when infection occurs, as they are one of the first lines of defense of the body [27-29]. However, the lack of adequate data on the role of rice bran extracts in altering blood parameters in poultry requires further research.As expected, asincreasing inclusion level of RBE in diets decreased (linear, $P<0.01$ ) the concentrations of total cholesterol (Table 5). AST, ALT, glucose, and albumin were not affected by inclusion of RBO in diets. ANITHA et al. [13] reported that dietary supplementation of rice bran extracts decreased the concentrations of total serum cholesterol in broilers. Several studies on humans and animals [22, 30-32] showed that rice bran extracts lowered the level of low-density lipoprotein cholesterol and total serum cholesterol or enhancing the conversion of cholesterol to fecal bile acids and sterols. Levels of lipid serum (total cholesterol, beta lipoprotein, and LDL cholesterol) decreased significantly [33]. It was concluded that oryzanol was at least partly responsible for the cholesterol lowering action of RBE and is associated with the reduction in aortic fatty streak formation. $\gamma$-oryzanol can also lower the plasma cholesterol level [34]. Although the

Table 6 Immune response of broiler chickens fed the diet containing rice bran oil $(\mathrm{RBO})^{\mathrm{a}}$

\begin{tabular}{|c|c|c|c|c|c|c|c|}
\hline \multirow[t]{2}{*}{ Items } & \multicolumn{4}{|c|}{ Dietary treatments ${ }^{\mathrm{b}}$} & \multirow[t]{2}{*}{ Pooled SEM ${ }^{c}$} & \multicolumn{2}{|c|}{$P$-value } \\
\hline & 0 & 5 & 10 & 20 & & Linear & Quadratic \\
\hline $\operatorname{lgG}(\mathrm{mg} / \mathrm{mL})$ & 1.26 & 1.56 & 1.56 & 2.51 & 0.51 & 0.01 & 0.27 \\
\hline $\operatorname{lgM}(\mu \mathrm{g} / \mathrm{mL})$ & 132.2 & 259.7 & 162.6 & 225.9 & 82.18 & 0.63 & 0.71 \\
\hline
\end{tabular}

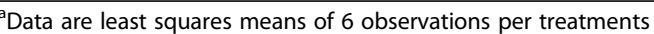

${ }^{b}$ Basal diet was supplemented with RBO at 5,10 , or $20 \mathrm{~g} / \mathrm{kg}$

'Pooled standard error of the means 
mechanism underlying this effect is not apparent at present the presence of oryzanol and tocopherols in the rice bran is thought to be responsible for this favorable effect. Nutritional and biochemical aspects of the hypolipidemic action of rice bran extracts have been reviewed by Rukmini and Raghuram [35]. Increasing inclusion level of RBE in diets increased concentrations of IgG (linear, $P<0.01$ ). There was no effect of inclusion level of RBE in diets on concentrations of IgM (Table 6). RBO effect on the immune response has been suggested to be due to its adequate mixture of essential fatty acids, and unsaturated fatty acid. Yang et al. [36] reported that vegetable oil such as canola oil has been recognized as adequate mixture of essential fatty acids, and unsaturated fatty acid such a linolenic acid that can improve broiler performance, also linolenic acids can be converted to longer chain omega- 3 fatty acid. The action of $n-6$ PUFA as a pro-inflammatory factor and the action of n-3 PUFA as an anti-inflammatory factor is well documented [37]. Dietary lipid source may affect immuno-competence via affecting membrane fatty acid composition and therefore fluidity, flexibility and function and affecting the inflammatory process and other cell signaling pathways [38]. Our result suggested immunomodulatory effects produced by the consumption of RBO, which also indicate that $\gamma$-oryzanol is not responsible for the overall immuno-regulation despite having important roles in other organism functions. In fact, $\gamma$-oryaznol modifies the immune response in a different way to the one observed for RBO. Thus, fatty acid composition could be responsible for the effects of RBO. A high concentrations linoleic acid consumption could be responsible for the increase in lymphocyte proliferation, spleen size and TH1 repsonse as suggested by other in vivo and in vitro studies using linoleic acid [39-41]. RBO contains an important fraction of linoleic acid, and the effects described in the above mentioned studies are also observed in our study.

\section{Conclusion}

The results of this study indicate that dietary supplementation of rice bran extracts improves growth performance and decreases total cholesterol level in broilers. Therefore, dietary rice bran extracts is considered a valuable functional ingredient to improve the growth performance of birds.

\section{Competing interests}

The authors declare that they have no competing interests.

\section{Authors' contributions}

CHK designed the experiment, wrote the manuscripts, and performed the statistical analysis. HKK revised the manuscript. Both authors were responsible for interpreting the data, added scientific comments, and approved the final version of the manuscript.

\section{Acknowledgements}

This work was carried out with the support of "Cooperative Research Program for Agriculture Science \& Technology Development (Project title: Development of fermented feed using poultry by-product of rice processing, Project No.

PJ009475)" Rural Development Administration, Republic of Korea.

Received: 3 January 2016 Accepted: 4 February 2016

Published online: 15 March 2016

\section{References}

1. Lee TT, Ciou JY, Chiang CJ, Chao YP, Yu B. Effect of Pleurotuseryngii stalk reisidue on the oxidative status and meat quality of broilers. J Agric Food. 2012:60:11157-63.

2. Hamada J. Characterization and functional properties of rice bran poteins modified by commercial exoproteases and endoproteases. J Food Sci. 2000;65:305-10.

3. Ryan EP. Bioactive food components and health properties of rice bran. J Am Vet Med Assoc. 2011;238:593-600.

4. Ryan EP, Heuberger AL, Weir TL, Barnett B, Broeckling CD, Prenni JE. Rice bran fermented with Saccharomyces boulardii generates novel metabolite profiles with bioactivity. J Agric Food Chem. 2011;59:1862-70.

5. Warren BE, Farrell DJ. The nutritive-value of full-fat and defatted rice bran. 2 . Growth studies with chickens, rats and pigs. Anim Feed Sci Technol. 1990:27:229-46.

6. McCaskill DR, Zhang F. Use of rice bran oil in foods. Food Technol. 1999;53:50-3.

7. Raghuram TC, Rukmini C. Nutritional significance of rice bran oil. Indian J Med Res. 1995;102:241-44.

8. Johnson LA, Lusas EW. Comparison of alternative solvents for oil extraction. J Am Oil Chem Soc. 1983;60:229-42.

9. Lakkakula RL, Lima NM, Terry W. Rice bran stabilization and rice bran oil extraction using ohmic heating. Bioresource Technol. 2004;92:157-61.

10. Jo $\mathrm{HH}$, Choi $\mathrm{YH}$. Optimization of ethanol extraction of $\mathrm{\gamma}$-oryzanol and other functional components from rice bran. Kor J Food Preserv. 2010;17:281-89.

11. Juliano C, Cossu M, Alamanni MC, Piu L. Antioxidant activity of gammaoryzanol: mechanism of action and its effect on oxidative stability of pharmaceutical oils. Int J Pharm. 2005:299:146-54.

12. Amarasinghe BMWPK, Gangodaviage NC. Rice bran oil extraction in Sri Lanka: data for process equipment design. Food Bio-prod Process. 2004;82:54-9.

13. Anitha B, Moorthy M, Viswanathan K. Production performance of broilers fed with crude rice bran oil. Int J PoultSci. 2006;5:1046-52.

14. Purushothaman MR, Vasan P, Mohan B, Ravi R. Utilization of tallow and rice bran oil in feeding broilers. Ind J Poult Sci. 2005:40:175-78.

15. Berger A, Rein D, Schafer A, Monnard I, Gremaud G, Lambelet P, et al. Similar cholesterol-lowering properties of rice bran oil, with varied $\gamma$ oryzanol, in mildly hypercholesterolemic men. Euro JNutr. 2005;44:163-73.

16. Henderson AJ, Kumar A, Barnett B, Dow SW. Consumption of rice bran increases mucosal immunoglobulin a concentrations and numbers of intestinal lactobacillus spp. J Med Food. 2012;15:469-75.

17. AOAC. Official method of analysis. 15th ed. Arlington, VA: Assoc. Off. Anal. Chem; 1990.

18. NRC. Nutrient requirements of poultry. 9th ed. Washington, DC: Natl. Acad. Press; 1994.

19. Steel RGD, Torrie JH, Dickey DA. Principles and procedures of statistics: a biometrical approach. 3rd ed. New York: McGraw-Hill Companies; 1997.

20. Murugesan $V$. Utilization of soapstock as an energy source in broiler ration, M.V.Sc., thesis submitted to Tamil Nadu Veterinary and Animal Science University, Chennai; 1997.

21. Purshothaman MR, Vasan P, Ravi R, Mohan B. Shothaman, MR, P Vasan, R Ravi, BMohan. Effect of palm oil, rice bran oil and tallow on broiler production. Souvenir, Lead Papers and Research Abstracts in IPSACON. 2000;52:104

22. Sharma RD, Rukmini C. Rice bran oil and hypocholesterolemic in rats. Lipids. 1986:21:715-17.

23. Rahimi S, Kamran Azad S, KarimiTorshizi MA. Omega-3 enrichment of broiler meat by using two oil seeds. J AgrSci Tech. 2011;13:353-65.

24. Baiao NC, Lara LJC. Oil and fat in broiler nutrition. Braz J Poult Sci. 2005;1:129-41.

25. Lesson S, Summers JD. Nutrition of the chicken. 4th ed. Ontario: University Books; 2001. p. 413. 
26. Lstsshaw JD. Daily energy intake of broiler chickens is altered by proximate nutrient content and form of the diet. Poult Sci. 2008:87:89-95.

27. Ganong WF. Review of Medicinal Physiology. 19th ed. Stanford, Conneecticut, Appleton and Lange;1999.p.353.

28. Alzawqari M, Moghaddam HN, Ragi AR. The effect of desiccated ox bile supplementation on performance, fat digestibility, gut morphology and blood chemistry of broiler chickens fed tallow diets. J Appl Anim Res. 2011;39:169-74.

29. Masoudi A, Chagi M, Bojarpour M, Mirzadeh K. Effects of different levels of date pits on performance, carcass characteristics and blood parameters of broiler chickens. J Appl Anim Res. 2011;39:399-405.

30. Hegsted M, Windhauser MM. Reducing human heart disease risk with rice bran. Louisiana Agric. 1993;36:22-4.

31. Kahlon TS, Saunders RM, Sayre RN, Chow FI, Chiu MM, Betschart AA. Cholesrerol-lowering effects of rice bran and rice bran oil fractions in hypercholestrolemic hamsters. Cereal Chem. 1992;69:485-89.

32. Nicolosi RJ, Ausman LM, Hegsted DM. Rice bran oil lowers serum total and low density lipoprotein cholesterol and apo B levels in nonhuman primates. Artheroscelerosis. 1991;88:133-42.

33. Moriyama N, Shinozaki T, Kanayama K, Yamoti S. Development of the processing rice which added new functionality. Nippon-Nogeikagaku-Kaishi. 2002; 76:614-20

34. Nestel PJ. Dietary fibre. Med J Austr. 1990;153:123-24.

35. Rukmini C, Raghuram TC. Nutritional and biochemical aspects of the hypolipidemic action of rice bran oil: a review. J Am Coll Nutr. 1991;10:593-601.

36. Yang CX, Ji C, Ding LM, Rong Y. N-3 fatty acid metabolism and effect of alpha-linolenic acid on enriching n-3 FA eggs. J Chi Agri Uni. 2000;95:117-22.

37. Calder P. Polyunsaturated fatty acids, inflammation, and immunity. Lipids. 2001;36:1007-24

38. Trushenski JT, Lochmann RT. Potential, implications and solutions regarding the use of rendered animal fats in aquafeeds. Am J Anim Vet Sci. 2009:4:108-28.

39. Kuratko CN. Proliferation of colonic lymphocytes in response to inflammatory cytokines is lower in mice fed fish oil than in mice fed corn oil. Cancer Lett. 2000;148:27-32.

40. Henning B, Meerarani P, Ramdass P, Watkins BA, Tobrek M. Fatty acidmediated activation of vascular endothelial cells. Metabolism. 2000:49:1006-13.

41. Zusmam I, Ben-Hur H, Budovsky A. Transplacental effects of maternal feeding with high fat diets lipid exchange and response of the spleenic lymphoid system in mice offspring exposed to low doses of carcinogen. Int J Mol Med. 2000:6:337-43.

\section{Submit your next manuscript to BioMed Central and we will help you at every step:}

- We accept pre-submission inquiries

- Our selector tool helps you to find the most relevant journal

- We provide round the clock customer support

- Convenient online submission

- Thorough peer review

- Inclusion in PubMed and all major indexing services

- Maximum visibility for your research

Submit your manuscript at www biomedcentral.com/submit

) Biomed Central 